\title{
Aortic body tumors in dogs from Northern Paraná, Brazil
}

\author{
Tumores do corpo aórtico em cães do Norte do Paraná, Brasil
}

\author{
Selwyn Arlington Headley ${ }^{\mathrm{I}}$ Ana Paula Bracarense ${ }^{\mathrm{II}}$ Tizianne Nakagawa $^{\text {III }}$ \\ Kleber Moreno ${ }^{\mathrm{II}}$ Patrícia Mendes Pereira ${ }^{\mathrm{IV}}$ Antônio Carlos Faria dos Reis ${ }^{\mathrm{II}}$
}

\begin{abstract}
This article describes the occurrence of aortic body tumors in four dogs from Southern Brazil. All dogs were males, more than 9 year of age; most of these were from the Boxer breed of dogs. The animals had large neoplastic growths at the base of the heart, which demonstrated histologic characteristics consistent with that of aortic body tumor. By immunohistochemistry, tissue sections from all dogs reacted positively to neuron specific enolase. These cases might represent the first description of this tumor in dogs from Brazil, as confirmed by immunohistochemistry.
\end{abstract}

Key words: dog, heart, aortic body tumor, immunohistochemistry, neuron specific enolase.

\section{RESUMO}

Este artigo descreve a occorência de tumores do corpo aórtico em quatro cães provenientes do Sul do Brasil. Todos os cães eram machos com mais de 9 anos de idade; a maioria deles era da raça Boxer. Os animais tiveram crescimentos neoplásticos grandes na base do coração, os quais demonstraram característicias histológicas consistentes com o tumor aórtico. Através da imunohistoquímica, cortes de tecidos de todos os animais eram positivos para enolase neuronal especifica. Esses casos provavalmente representam à primeira descrição desse tumor em cães do Brasil, os quias foram confirmados por imunoistoquímica.

\author{
Palavras-chave: cão, coração, tumor do corpo aórtico, \\ imunoistoquímica, enolase neuronal \\ especifica.
}

Chemoreceptor cells are responsible for changes in blood $\mathrm{pH}$, oxygen tension, and carbon dioxide content (JOHNSON, 1968; CAPEN, 2007). These cells occur in several body locations such as the carotid body, aortic body, nodose ganglion of the vagus nerve, ciliary ganglion in the orbit, pancreas, bodies on the internal jugular vein below the ear, and glomus jugulare located at the recurrent branch of the glossopharyangeal nerve (CAPEN, 2002; 2007). Neoplasms of these cells are termed chemodectomas or nonchromaffin paragangliomas (JOHNSON, 1968; CAPEN, 2002), and are frequently described in the aortic and carotid bodies of domestic animals (CAPEN, 2002).

Aortic body tumors are located at the base of the heart within the pericardial sac, and are more frequently observed between the aorta and the pulmonary artery (JOHNSON, 1968). Alternatively, carotid body tumors arise medially at the bifurcations of the common carotid artery; these tumors are

'Department of Basic Veterinary Sciences, School of Veterinary Medicine, St. Matthew’s University, Grand Cayman, Cayman Islands, British West Indies. KY1-1209. Phone: +345-745-3199 Ext. 4007. E-mail: sheadley@smu.ky. Corresponding author.

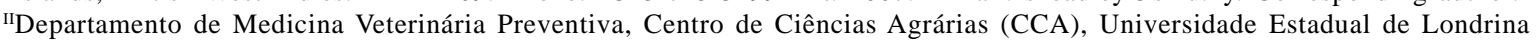
(UEL), Londrina, Paraná, Brasil.

IIILaboratory of Veterinary Pathology, Faculty of Applied Biological Sciences, Gifu University, Gifu, Japan.

${ }^{\mathrm{IV}}$ Departamento de Clínicas Veterinárias, CCA, UEL, Londrina, PR, Brasil. 
intimately attached to the origins of the occipital and ascending pharyngeal arteries (HUBBEN et al., 1960; DEAN \& STRAFUSS, 1975). This communication describes the clinical, laboratory, pathologic, and immunohistochemical findings associated with aortic body tumors in dogs from Paraná, Southern Brazil.

The age, breed, and sex of the dogs used in this report are given in table 1 . The available clinical records and the laboratory findings of these animals were reviewed and organized (Table 2). These represent cases of aortic body tumors diagnosed by histopathology at the Laboratory of Veterinary Pathology, Universidade Estadual de Londrina, during 1993-2006, and are from dogs submitted for routine necropsy after euthanasia or spontaneous death. The major gross findings were reviewed and tabulated (Table 1). Histologic description was done by using sections that were routinely stained with Hematoxylin and Eosin (HE).

A biotin-streptavidin-horseradish peroxidase commercial detection kit (Dako, CA, USA) was utilized for the immunohistochemical evaluation. A primary mouse monoclonal antibody to human neuron specific enolase (clone BBS/NC/VI-H14, 1:100, Dako) was used. The protocol done in this study was based on a previous description (BROWN et al., 2003) with modifications. Brain sections from normal dogs served as positive control; for negative controls, PBS substituted the primary antibody.
Six cases of aortic body tumors were diagnosed in dogs by histopathology during the 13year evaluation period. However, tissue blocks for two of these were not located and withdrawn from the study. All dogs were males between 9-15 years of age; three represented the Boxer breed and one Great Dane. Clinically, two dogs had swollen limbs, one with pulmonary edema, and another with locomotory difficulties; three were euthanized due to unfavorable prognosis; one died spontaneously (Table 1). Clinical laboratory evaluations were done in all dogs except № 4; Dog 1 was anemic with a non-regenerative response; Dog 2 had discrete elevation of serum albumin, while the values of renal enzymes were elevated in Dog 3; all remaining clinical parameters were within normal limits (Table 2).

During routine necropsy, large (3-4 x 3-5 x 6$8 \mathrm{~cm})$, extensive, solid, tumorous masses with smooth external surfaces were observed at the heart base of all dogs. The cut surfaces were white-cream, nodular with mottled brown and red areas (Figure $1 \mathrm{~A}-\mathrm{C}$ ). The most frequently observed necropsy findings included bloodfilled body cavities (Figure 1-D) and pulmonary edema (75\%; 3/4), followed by anasarca (50\%; $2 / 4)$ and nutmeg liver (50\%; 2/4); a concomitant cutaneous mast cell tumor was diagnosed in dog 4 .

Histology revealed chemodectomas characterized by extensive sheets of neoplastic chemoreceptor cells that were divided into various

Table 1 - Animal signalment and associated findings in canine chemodectoma.

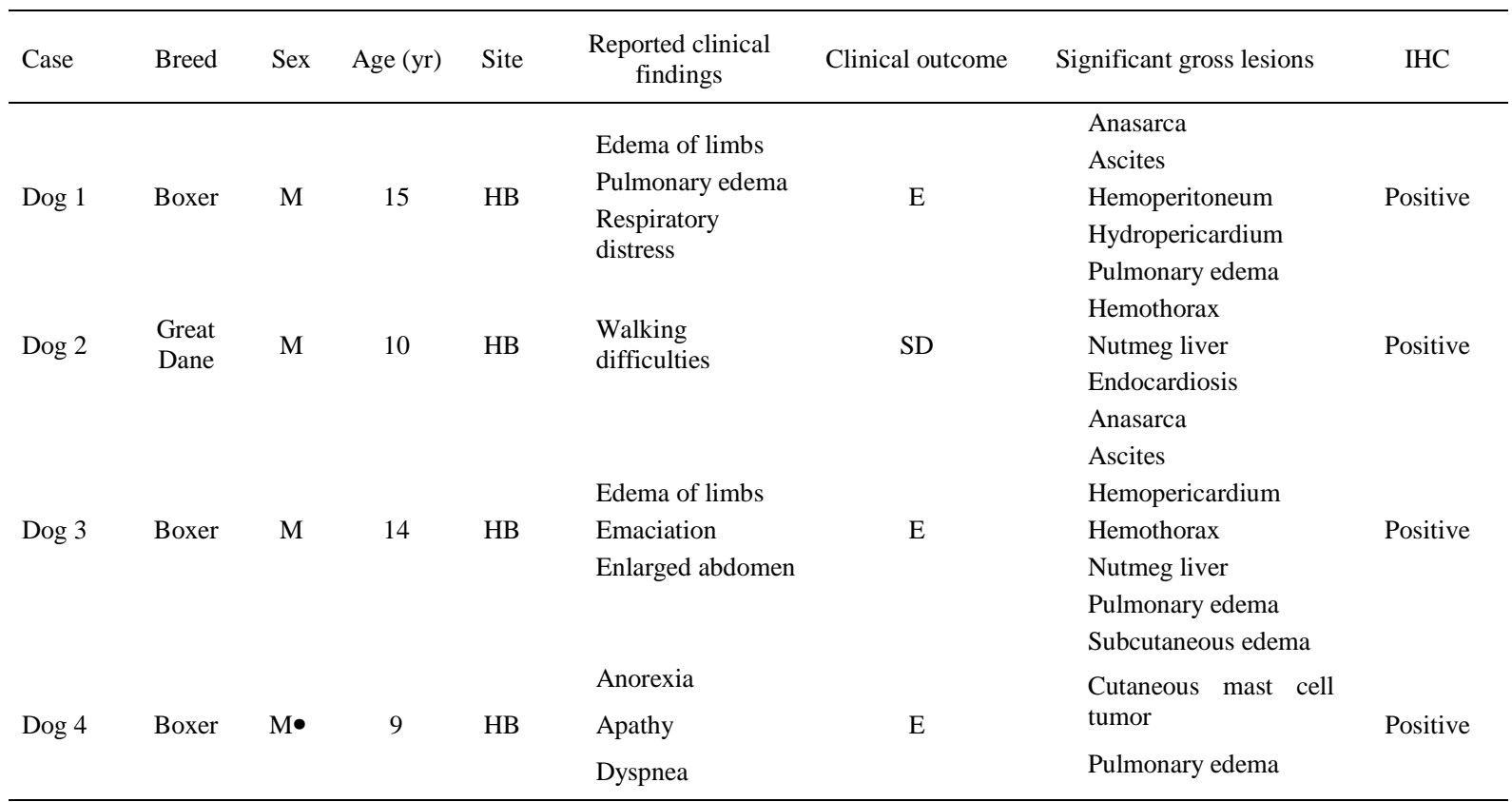


Table 2 - Summary of laboratory values in dogs with chemodectoma.

\begin{tabular}{|c|c|c|c|c|}
\hline Laboratory parameters & Reference values & $\operatorname{Dog} 1$ & Dog 2 & $\operatorname{Dog} 3$ \\
\hline \multicolumn{5}{|l|}{ Hemogram } \\
\hline Hematocrit (\%) & $37-55$ & 26.9 & 46.8 & 50.6 \\
\hline Hemoglobin $\left(\mathrm{g} \mathrm{dL}^{-1}\right)$ & $12-18$ & 10.4 & 15.1 & 15.7 \\
\hline Red blood cells (x $10^{6} \mathrm{~mm}^{-3}$ ) & $5.5-8.5$ & 4.02 & 8.1 & 8.8 \\
\hline Leucocytes $\left(\mathrm{mm}^{-3}\right)$ & $6.000-17.000$ & 14.410 & 27.500 & 11.390 \\
\hline Neutrophils $\left(\mathrm{mm}^{-3}\right)$ & $3000-11500$ & 13.977 & 26.400 & 9.567 \\
\hline Platelets $\left(\mathrm{x} 10^{3} \mathrm{~mm}^{-3}\right)$ & $200-500$ & ND & 554 & 220 \\
\hline Lymphocytes $\left(\mathrm{mm}^{-3}\right)$ & $1000-4800$ & 288 & 1.100 & 1.252 \\
\hline Eosinophils $\left(\mathrm{mm}^{-3}\right)$ & $0-1250$ & 0 & 0 & 0 \\
\hline Band neutrophils $\left(\mathrm{mm}^{-3}\right)$ & $0-300$ & 144 & 0 & 569 \\
\hline Monocytes $\left(\mathrm{mm}^{-3}\right)$ & $0-1350$ & 0 & 0 & 0 \\
\hline MCV (fl) & $58-73$ & 67.2 & 57.7 & 57.5 \\
\hline MCHC $\left(\mathrm{g} \mathrm{dL}^{-1}\right)$ & $28-40$ & 38.6 & 32.2 & 30.9 \\
\hline MCH (pg) & $19.5-24.5$ & 26 & 18.6 & 17.8 \\
\hline \multicolumn{5}{|l|}{ Serum chemistry } \\
\hline Creatinine (mg dL ${ }^{-1}$ ) & $0.5-1.5$ & ND & 3.6 & 1.0 \\
\hline Urea $\left(\mathrm{mg} \mathrm{dL}^{-1}\right)$ & $10-24$ & ND & 104.6 & ND \\
\hline $\operatorname{ALT}(\mathrm{U} / \mathrm{L})$ & $21-102$ & 76.8 & 15.6 & ND \\
\hline FA (U/L) & $20-156$ & 226.6 & 70.2 & ND \\
\hline Albumin & 2.6-3.3 & ND & 3.8 & ND \\
\hline
\end{tabular}

ND, not done.

lobules by connective tissue; these were further subdivided into smaller nest-like structures by thin strands of fibrous septae. The neoplastic cells were cuboidal or polyhedral, the cytoplasm was slightly eosinophilic-granular, nuclei were rounded to oval and centrally located (Figure 1-E). By immunohistochemistry (IHC), the tissues sections from all dogs reacted positively to NSE, with similar intensity and distribution of immunoreactivity (Figure 1-F); the negative controls remained unstained.

In these cases, an initial diagnosis of aortic body tumor was based on gross features, the anatomic location of the neoplastic growths, and the histologic pattern of the neoplasm; immunoreactivity to NSE confirmed these findings. The morphologic, anatomic and histologic findings of these cases are consistent with that of canine aortic body tumor, and of previous descriptions (BALAGUER et al., 1990; CAPEN, 2002; BROWN et al., 2003; CAPEN, 2007). Additionally, the positive NSE immunoreactivity was similar to other reports of chemodectomas in dogs (BALAGUER et al., 1990; BROWN et al., 2003).

The results described in this report are similar to the natural occurrence of this neoplasm in dogs. The brachycephalic breeds of dogs are considered highly susceptible to chemodectomas (JOHNSON, 1968; DEAN \& STRAFUSS, 1975;
KISSEBERTH, 2001), and there is an apparent male predisposition (JOHNSON, 1968; CAPEN, 2002); during this study, only male dogs were diagnosed with aortic body tumors. Further, the Boxer and the Boston terrier breeds of dogs are more susceptible to chemodectomas than other breeds (JOHNSON, 1968); although there were few cases diagnosed during this study, $75 \%$ of these represented the Boxer breed of dog. Most cases of canine chemodectoms occur in animals that are 8years-of-age or older (JOHNSON, 1968; DEAN \& STRAFUSS, 1975; Capen, 2002); all dogs herein described were more than nine years of age. Therefore, the occurrence described in this report might possibly represent the natural distribution of canine aortic body tumors in Southern Brazil. However, additional cases are needed to confirm this hypothesis. Nevertheless, to the best of the authors' knowledge, this report might represent the first cases of canine chemodectoma confirmed by IHC in Brazil.

The clinical manifestations (pulmonary edema, dyspnea, and edema of limbs) and gross lesions (anasarca, ascites, hydropericardium, nutmeg liver, and pulmonary edema) in most of these dogs are manifestations of cardiac decompensation and congestive heart failure associated with this tumor (JOHNSON, 1968; CAPEN, 2002). The clinical laboratory findings described in this study were not 


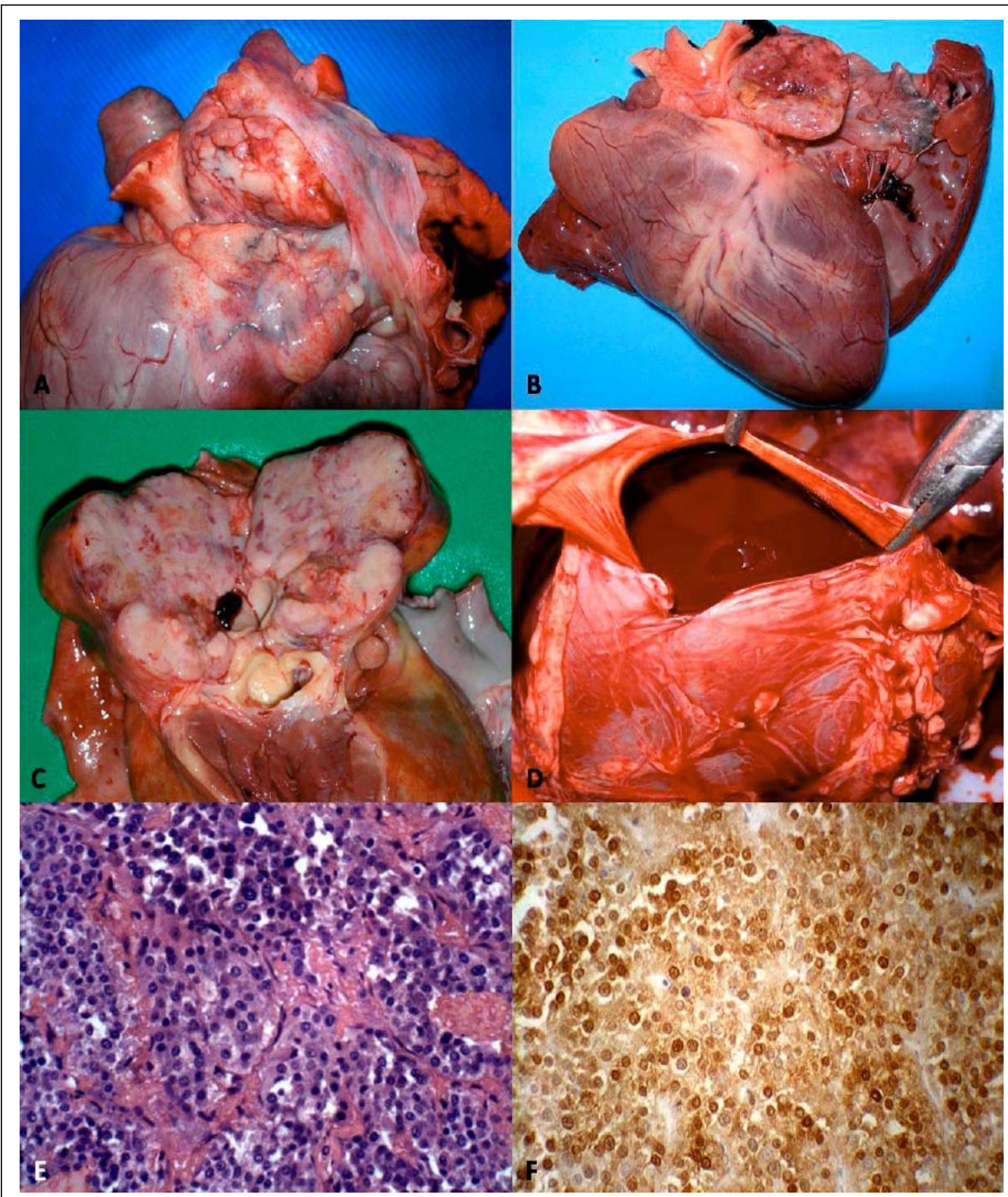

Figure 1 - Aortic body tumor in dogs. There is a large mass at the base of the heart; Boxer dog, A. Nodular smooth cut surface of the heart base tumor; heart; Great Dane dog, B. Observe the nodular pattern and the mottled background of the tumorous mass; heart; Boxer dog, C. Blood-filled pericardial sac; D. Tumor cells are divided into small nest-like structures that are surrounded by thin septa of connective tissue; heart, HE, 40x Obj. E. Most cells are intensely immunoreactive to neuron specific enolase. IHC, biotinstreptavidin-horseradish peroxidase. 40x. Obj. F.

suggestive of neoplastic processes, but only reflected the consequences of the neoplastic growth in one dog that had severe loss of blood; these results suggest that routine clinical laboratory evaluations might not be of any diagnostic significance in canine chemodectoma. Gross findings, such as hemothorax and hemopericardium, might be due to rupture or the compression of blood vessels (CAPEN, 2002), and would have been responsible for the anemia observed in dog 1. Additionally, the only concomitant neoplastic lesion was a mast cell tumor, diagnosed in dog $n^{\circ} \mathbf{4}$; this tumor and other concomitant neoplasms have been 
previously described with chemodectomas (JOHNSON, 1968), but their direct association, if any, has to be investigated.

\section{CONCLUSIONS}

Aortic body tumors were diagnosed in dogs based on gross features and histopathologic findings that are consistent with this neoplasm. Immunohistochemistry confirmed the diagnosis by positive immunoreactivity to neuron specific enolase. This report probably represents the first cases of IHCconfirmed chemodectoma in dogs from Brazil.

\section{REFERENCES}

BALAGUER L. et al. Incidental findings of a chemodectoma in a dog: differential diagnosis. Journal of Veterinary Diagnostic Investigation, v.2, p.339-341, 1990.

Brown P. J., et al. Immunohistochemical characteristics of canine aortic and carotid body tumors. Journal of Veterinary Medicine. A, v.50, p.140-143, 2003.
CAPEN C.C. Tumors of the endocrine glands. In: MEUTEN, D.J. Tumors in domestic animals. 4.ed. Ames: Iowa State, 2002. Chap.13. p.607-696.

CAPEN C.C. The endocrine glands. In: MAXIE, M.G. Jubb, Kennedy, and Palmer's Pathology of domestic animals. 5.ed. Philadelphia: Saunders/Elsevier, 2007. V.3, p.325-428.

DEAN M.J.; STRAFUSS A.C. Carotid body tumors in the dog: a review and report of four cases. Journal of the American Veterinary Medical Association, v.166, p.1003-1006, 1975 .

HUBBEN K., et al. Carotid body tumor in the dog. Journal of the American Veterinary Medical Association, v.137, p.411-416, 1960.

JOHNSON K.H. Aortic body tumors in dogs. Journal of the American Veterinary Medical Association, v.152, p.154160, 1968.

KISSEBERTH W.C. Neoplasia of the heart. In: WITHROW, S.J.; MACEWEN, E.G. (Eds). Small animal clinical oncology. 3.ed. Saunders. Philadelphia, 2001. p.661-667.

PALTRINIERI S et al. Pathological and immunohistochemical findings in a feline aortic body tumor. Veterinary Pathology, v.41, p.195-198, 2004. 